How to Cite

Haliim, W. (2018). Harmony and tolerance as a tengger identity: reflections for Indonesian identity and unity

degradation. International Journal of Social Sciences, 1(1), 1-8. https://doi.org/10.31295/ijss.v1n1.1

\title{
Harmony and Tolerance as a Tengger Identity: Reflections for Indonesian Identity and Unity Degradation
}

\author{
Wimmy Haliim \\ Brawijaya University, Indonesia \\ Email:wimmyfisip@ub.ac.id
}

\begin{abstract}
The degradation of our Identity and Indonesian Unity is an important issue to be discussed. The Conflict number Because of Ethnic, Religion, and Race (SARA), which always occur in various regions in Indonesia is the fact that the Identity and National Unity has degraded. Through Phenomenology Research Methods, researchers doing research to lift to the surface on the local wisdom of the Tengger's in Ngadas Village, District Poncokusumo, Malang. The Local Wisdom Such is the Identity of Tengger. Tengger Identity is Harmony and Tolerance. Religious differences are not a problem for them, because of the attitude of harmony and tolerance entrenched for a long time. The impact, in some decision making of political or social issues. The Tengger's never used Voting, but the Musyawarah untuk Mufakat (The Council for Consensus). Thus, the Unity community is a positive result obtained by the Tengger's. In the end, the phenomena Ngadas village could be a reflection and a reference for us to reflect and initiate back the Identity and National Unity of the United Nation of Indonesian Republic.

Keywords---harmony religious tolerance, identity degradation, indonesian unity, Tengger identity.
\end{abstract}

\section{Introduction}

In 2009, the Central Bureau of Statistics found 1,128 ethnic groups in Indonesia. Central Bureau of Statistics (Bakosurtanal), in 2006 published 726 local languages used as a communication tool in Indonesia (Pratiwi, 2012). This diversity carries a high tolerance for each individual. For the sake of peace and sustainability of a country, the tolerance will reduce the potential for conflict in Indonesia. 1.128 is not a small number if it should be placed on 17 thousand islands in this country. Even this number exceeds the number of countries recognized by the world. With this condition, again, tolerance is no longer an appeal, but it becomes a key for Indonesia to maintain its country's stability.

However, his current condition is not as it should be. Indonesia is often hit by conflicts in the region. Beginning of East Timor (East Timor) at the beginning of reformation, followed by riots between ethnic groups, religion and race (SARA) in Lampung, Poso, Sampit, and Sampang. Then the emergence of Separatist Movements such as GAM (Free Aceh Movement) or OPM (Organization of Free Papua). The example of such cases is nothing but proof that we as a great nation experience the degradation of National Identity and Unity.

Need for learning for the community to re-reflect the values contained in the philosophy-Unity Diversity Unity because 'Indonesian Unity' remains to be seen fragile (Leksono, 2010). Whereas unity is part of the foundation of this nation. In the end, this should be a big task for the community to re-unite unity and togetherness for the better development of the nation. In remote areas of Indonesia, there is a village which, according to the author, can be used as an example for Indonesian society today, especially in view of the diversity that exists. The area is located in Ngadas Village, Poncokusumo District, Malang Regency, East Java Province is a village with a high tolerance level of diversity. In this village, there are three religions adopted by the people. Buddhism, Hinduism, and Islam. These three religions come together in one village and together build their village*. This diversity is clearly based on an understanding of the high values of the culture it has. It is Tengger, the culture of this village that binds diversity into

Interview with Ngadas village chief on Thursday, May 9, 2013. The tenure of the village head is until the end of May 2013. Beginning in June 2013 , the village head is replaced with a newly elected village head.

ISSN 2632-9409

Received Jan 10, 2018 / Accepted Jun 20, 2018 / Published Jul 05, 2018 
a unity. For the people of this village, diversity is not a barrier to the pace of village development. Instead, for them this togetherness becomes its own added value ${ }^{\dagger}$.

\section{Research Method}

This research uses Phenomenology research method. Research methods Phenomenology describes the phenomenon on the basis of human behavior experienced in consciousness (Moleong, 2002). Researchers seek a person's understanding in building the concept and meaning that is intersubjective. Therefore, this research seeks to explain the meaning and experience of some people's life about a concept or phenomenon. The term phenomenology refers to all social views that place human consciousness and its subjective meaning as the focus for understanding social action (Moleong, 2004).

\section{Results and Analysis}

\section{Overview of Tengger Society}

From the time of Majapahit, the Tengger plateau was known as a peaceful, peaceful and even its people free from paying taxes called titileman (Titileman is a state ceremonial tax.) General Thomas Stamford Raffles greatly admired the Tengger people In The History of Java he argued that visiting the cool place, he saw the Tenggerese who lived in a peaceful, orderly, orderly, honest, diligent, and always happy way.He did not know gambling and opium. When Raffles asked about adultery, infidelity, theft, another type of crime, those commonly referred to as mountain people replied that these things were not found in Tengger (Sutarto, 1998: 21-37).

The honesty and sincerity of the Tenggerese can still be seen to this day. The crime rate in Tengger villages is generally almost always zero. The peaceful, peaceful, safe, and tolerant atmosphere reflected in the daily life of Tengger people can be used as a reference in the modern Indonesian formative period. Tengger is a heritage of saujana (cultural landscape) which, when properly guided and managed, its existence will make a more meaningful contribution not only for itself but also for Indonesia.

The people of Tengger are scattered in many villages in some districts in East Java. The villages within the 4 districts are predominantly Hindu and still adhere to the Tengger customs. The villages in question are Ngadas, Jetidak, Wonotoro, Ngadirejo, and Ngadisari (Sukapura, Probolinggo), Ledokombo, Pandansari and Wonokerso (Sumber Subdistrict, Probolinggo District), Tosari, Wonokitri, Sedaeng, Ngadiwono, Podokoyo (Tosari Sub- , Pasuruan District), Keduwung (Puspo Subdistrict, Pasuruan Regency), Ngadas (Poncokusumo Sub District, Malang Regency), and Argosari and Ranu Pani (District of Senduro, Lumajang District).

The Tenggerese are known as tough traditional farmers, living in clusters on hills not far from their farms. Cold air temperatures make them feel at work in the fields from morning until late afternoon. The percentage of the people who live as farmers is very large, ie $95 \%$, while a small percentage of them $(5 \%)$ live as civil servants, traders, laborers, and service businesses. Their service areas include renting horses for tourists, both domestic and foreign, being a jeep driver (usually his own), and renting rooms for tourists.

The main agricultural produce are vegetables, such as kobis, potatoes, carrots, garlic, and leek. Their land is also suitable for corn crops. At first, the corn is the staple food of the Tenggerese. At this time they are less likely to grow corn because of low economic value and replace it with vegetables that have high economic value. Even so, some of their agricultural lands is still planted with corn because not all Tengger people replace their staple food with rice. Only, to harvest corn, Tengger people have to wait long enough, almost a year. Until now the rice Tengger Aaron (corn rice) is still listed as a traditional food in the culinary treasures of the archipelago.

Tengger tribe is a tribe that is in the vicinity of Mount Bromo. The residents live in the district of Pasuruan, Probolinggo district, and Malang regency. The tribe closest to the Tengger tribe is the Javanese but there is a difference between the two, especially in the form of culture. Kurniasudar (2015) stated that the Tengger area is approximately $40 \mathrm{KM}$ from north to south and 20-30 KM from east to west, above the altitude between 1000M$3675 \mathrm{M}$. Tengger Caldera is the largest sand ocean, not at $2300 \mathrm{M}$, with a length of 5-10 KM. Crater of Mount Bromo, with a height of 2392M and still active. In the south tower the peak of Mount Semeru with 3676 altitudes.

The Hindu Tengger tribe lives in the area of Mount Bromo, Probolinggo Regency, East Java. In 1985 their number was about 40 thousand. There are many meanings contained from the word Tengger. Etymologically,

\footnotetext{
$\dagger$ The result of interview with head of Ngadas hamlet on Thursday, May 9, 2013. Head of Dusun Ngadas also serves as 'Senior citizen' in this village. That is, the head of Dusun Ngadas is the elder person in this village.
} 
Tengger means standing upright, stationary without moving (Java). When associated with custom and belief, the meaning of tengger is the tengering of virtue. This means that the sign that his citizens have a noble mind. Another meaning is mountainous area. Tengger is located on the slopes of Tengger and Semeru mountains.

There is also attribution of tengger with the myth of the community of husband and wife of the inhabitants of Tengger, namely Rara Anteng and Joko Seger. In addition, in this region, there are also stories about the history of Mount Batok, Lautan Pasir, Bromo Crater. Another story concerns Ajisaka Javanese script, also the story of Klambi Antrakusuma. The history of Tengger from the scientific side is closely related to the Tengger Inscription of 851 years Saka (929 AD), reinforced Inscription Penanjakan years 1324 Saka (1402 AD) (Savitri, 2010). Mentioned a village called Wandalit that terletidak in the Tengger mountains inhabited by Hulun Hyang (servant of God = religious people) whose surrounding area called hila-hila (holy). That's why the Tengger area is a special land of exemption which is exempt from tax payments by the central government in Majapahit. The people of Tengger are widely known Hindus, cohesive with traditional beliefs. Hindu society of Tengger is different from Hindu in Bali. The difference, among others, Hindu Tengger does not recognize Ngaben as a death ceremony as in Bali.

The Tengger community is a society whose majority of its citizens have a working background as a farmer. In its development, the Tengger Community cuts the trees to clear the land that will be used as agricultural land. The impact in some places, there is a hill that is not terraced and also very steep. So the Tengger Society faces a very serious erosion problem. The roads owned by the Tengger Society are mostly covered with sand and in many places reach a depth of ten centimeters. This trivial thing happened in one village of Tengger Society, that is Ranupani Village. During the dry season and high winds, the sand will blow into the lake Ranupani. According to Mr. Sarmin, (one of the Tengger Society who became the informant) from twenty years ago, the depth of the middle of the lake Ranupani is twenty meters, now the middle of the lake is a depth of about seven meters.

In its development, culturally the Tenggerese have been besieged by their brothers, the people of ngare, who have suffered from 'virus' of global capitalism. The modernization flows through products such as radio, television, video, VCD player, internet displaying luxuries, murders, violence, erotic and pornographic brutality, gossip and various whispers. Fortunately, the Tengger region, which has been physically regretted as a devastated area by environmentalists, is culturally saved.

They still survive as an agricultural society that has not been trapped in a consumeristic, materialistic, and hedonistic culture. Until when they can survive, everything will depend on the active heirs of the Tengger tradition, the Tengger dukun (Sutarto, 1999). The above description shows that although the Tengger region is under pressure both of economic, religious and cultural dimensions, Tengger shamans still play an active role in Walandhit and Majapahit traditions. It means that they perform worship in accordance with their beliefs and use Hindu-like ritual tools such as Gentha, Kropak, Prasen (holy water) and Prapen (place of fire and incense), and wear sampet (shawl, commonly used by Indu priests in Majapahit times).

They also still glorify Mount Bromo and other mountains around it. The Tenggerese, despite calling themselves Mountain people, are not politically blind. Nevertheless, they do not need political media to achieve social status, prestige, or access to power and therefore have never engaged in significant political conflicts. They, though already educated in college, prefer to be farmers rather than other professions. The spirit of pluralism embodied through cultural and religious attitudes makes Tengger people free from ethnic and religious dimensions.

Modern mass imaginations and exoticism captured through electronic media only make Tengger people stunned and amazed but not yet influenced by the lifestyles of the people or figures they see through the media. Most of the Tenggerese still position themselves as wong gunungan (people living on the mountain) different from wong ngare (people who live in flat places, in the lowlands or in the city). In the eyes of the mountain wong, wong ngare is full of gaps, many are rich, but many are poor, landless. According to the mountain wong, wong ngare is like to be alone and differentiate status. Wong ngare often judges a person from his rank. On the contrary, for the mountain wong, everyone is considered equal (padha) and one descendant (sakturunan). Because of padha and sakturunan, then in the life of mountain wong not known term kongkon (sending) others. The term is known as strong aids that are giving assistance to its neighbors because the workload of the neighbor is too heavy (Hefner, 1990).

\section{Rukun (Harmony), Foundation of Persatuan Ngadas Village}

Tengger tribe is a heritage of Majapahit Kingdom. With a spate of its history, placing these tribal people located around Mount Bromo and Semeru. Spread over dozens of villages in four districts (Malang, Lumajang, Probolinggo, and Pasuruan), Ngadas Village is located in Kecamatan Poncokusumo, Malang Regency. This village is the highest village in Malang Raya. The existence of this village is backed by triple stitch done by Mbah Sedek in the 1700s*.

\footnotetext{
* Interview with Ngadas village chief on Sunday, May 12, 2013.
} 
This village is also one of the dozens of villages where tengger people live. Even to this day, Ngadas Village is the only Tengger Tengger Village in Malang area. Like other Tengger people, in this village, Tengger custom rituals are held regularly. For the Tengger community, the implementation of customary rituals in each village is sufficient to say the village as Tengger Village ${ }^{\S}$.

Every village of Tenggerese people is always attached to their rituals, including the Ngadas Village community. Ceremonies Kasada, Karo, and Sodoran Dance are some of them (Sudiro, 2001). These cultural rituals are followed by all Tengger people, and even recently many local and international tourists are deliberately following the cultural ritual $^{* *}$. This reality is also not separated from the fact that Mount Bromo and Semeru has become a tourist area.

One thing that really needs to be known to the visitors of this village, there is still another side in the Village Ngadas in addition to the tourist objects. There are values that can be learned from this village, namely togetherness and harmony. According to Ngadas community itself, this harmony and togetherness exist because of the culture of Tengger which is the ancestral heritage of this tribe. As described above, in this village there are three religions adopted by the people. However, on top of this diversity, it is never written history that declared major conflicts ever happened in this village ${ }^{\dagger \dagger}$.

Sugih dunyo, nek sugih dolor, anguk sugih dolor ${ }^{\dagger}$ "Better too many brothers or friends than a lot of money or possessions". This philosophy forms harmony within this tribe. Brothers and friends not only mean having to multiple friends but also be interpreted as avoiding enmity. The cultivation of these values in each community of authors thinks it has been done well. Because it is proven, one week the writer doing research in Ngadas Village, warmth and togetherness is felt.

In addition, in the Tengger tribe, there are also values known as "welas asih pepitu." (Seven Love) (Waluyo, 1997):

1. Welas asih marang Bapa Kuasa (Love Toward God)

2. Welas asih marang Ibu Pertiwi (Love toward Motherland)

3. Welas asih marang Bapa Biyung (Love toward parent)

4. Welas asih marang rasa jiwa (Love toward soul)

5. Welas asih marang sepadane urip (Love toward human being)

6. Welas asih marang sato kewan (Love toward animals)

7. Welas asih marang tandur tetuwuh (Love toward plants)

Inside this foundation is an element that emphasizes tengger society to do good to human beings as well as other creatures of God's creation. All messages and teachings are expected to be embedded in every individual in society, believed to be true and exercised in everyday life. This is also why the people of Tengger are known for their harmony.

The manifestation of the values of harmony also not only happened recently. Because history records, the values of harmony have existed in this tribe long ago. Especially when many migrants enter the area, the fear of village tranquility arises, so in order to unite the people, dukuns in Tengger village use their traditional ceremony (Sudiro, 2001). In addition, there has been a dispute between non-Muslim religions with Islam, especially when Islam first entered this village. At that time, Intimidation by Non-Muslims against Muslims is quite strong. However, this does not cause latent conflict. Because the potential for this conflict was immediately muted by the village apparatus at the time $\S^{\S}$.

The strong application of harmony values in the Tengger Society, especially Ngadas Village, is not limited to that. Harmony in this village is also formed one of them by way of paguyuban ${ }^{* * *}$. The Circle of Friends is a life-form where members are bound by a pure, natural, eternal inner relationship. The basis of the relationship is love and sense of oneness (Soekanto, 2000). The manifestation of this community can be seen from the deliberation in policy and socialize to the public. In socialization, citizens are also allowed to convey their aspirations to the village apparatus. For example, if there is a cross-over of land boundaries, it will be called and resolved first at the village level, then if it can not be resumed at the district level (Waluyo, 1997).

$\S \quad$ Interview with Ngadas village chief on Saturday, May 11, 2013.

** Interview with Ngadas village chief on Thursday, May 9, 2013

$\dagger$ Interview with Ngadas village chief on Sunday, May 12, 2013.

Ibid

$\$$ The result of interview with Takat on Monday, May 13, 2013. Takat is the leader of Islam in Ngadas Village. According to his confession, he also spread Islam in this village.

*** Interview with Ngadas village chief on Saturday, May 11, 2013. 
With village apparatus formulating policies for the benefit of the village. The most obvious example is the presence of homestay coordinators in this village. The procurement of homestay coordinators in this village is motivated by the number of tourists passing through this village to Mount Bromo or Semeru with the aim of making tourist accommodations more coordinated ${ }^{\dagger \dagger}$. Thus, there is also a competition between citizens to compete for the benefits that will be in the can of tourists who overnight. Again, this is based on the values of harmony.

In addition, the community is also seen in the village head elections. Voting never happens in decision-making. Everything is cultivated by way of deliberation and consensus (Waluyo, 1997). It is carried out on the basis of the values of harmony. Harmony Ngadas Village community is no longer just a slogan owned by this village. Harmony seems to have taken root in every individual village Ngadas. Indirectly, these values of harmony form a bond and boundary for them. Thus, from such bonds and boundaries, there is a unity, the effort to move forward together.

\section{Tengger Identity}

Social identity is closely related to the identification process. Through an identification process built on integrity with its environment, identity quickly and slowly forms and becomes the cloak it employs to interact with the outside world. The individual (self) no longer identifies himself as something real. He will always see the other side of himself to be a reflection of himself. In this way, the subject succeeds to identify itself (Purwanto, 2007). Speaking of the social environment in the role-playing the role of identity, involved also in it cultural themes. Thus, there is another concept of identity, the cultural identity. Cultural identity can be interpreted as a breakdown of characteristics or cultural traits possessed by a person who is known to be boundaries when compared with other people's characteristics or cultural traits (Samovar, 2010).

The next cultural identity automatically becomes the regulation of individual attitudes and behavior. Simply, this identity is like the cultural cloak that individuals use in socializing. Thus, cultural norms will or will not bring the cultural norm along with his cloak. It is these norms that will lead and limit the movements of the individual. This is because, indeed, social norms (especially cultural norms) of culture will govern how individuals in groups should behave and behave (Purwanto, 2007).

One example exists on the author's analysis of the interview with Takat as the leader of the Islamic religion. Takat says: "saya kan wong Tengger, makanya saya harus rukun" (I am a Tengger people, therefore I must live harmoniously.). This statement can already represent it. When he says "I am a Tengger" this is a form of his identification of Tengger culture. In other words, Takat has a Tenggerese cultural identity. Then, he said, "so I have to live in harmony". This is a consequence that must be received as a person who already has the identity of Tengger. Then, Tengger culture is close to the values of harmony. Thus, as a Tengger, Takat must behave in accordance with his Tengger's values to prove that he is a Tengger as well. From this, we can see how cultural identity can influence human behavior.

In Ngadas Village, cultural identity is not only owned by Takat alone as a religious leader. Almost all villagers in the village have it. Thus, the homogeneity of this cultural identity appears as a frame governing the attitude and behavior of the community in Ngadas Village. Harmony, collective behavior owned by Ngadas Village community, carried out and give each other reinforcement. Culture is the prize.

\section{Tengger and Tolerance Culture}

As in the previous sections, the village of Ngadas is very thick with the values of harmony. Rukun is a system used as the capital of interacting with each other. Which then should be the question, what makes this village community run culture well? Tolerance is the answer. The most extreme meaning of tolerance is the ability to accept the reality of a life of pain (Pendit, 2001). The meaning of this tolerance is too much to study. Indonesian refers to tolerant simplicity, which is the nature or tolerance (respect, letting, allow) of opinion (opinions, views, beliefs, customs, behavior, etc.) that are different or contrary to their own stance (Indonesian Dictionary, 2008). So tolerance is a tolerant attitude.

Inter-religious conflicts, such as the Ketapang and Ambon conflict, involving two groups of people in the name of religion, should not have occurred, if they still involve tolerance values in their interactions. Mutual respect and respect for the differences of others should be able to bring them to realize the difference is not a barrier to the realization of fraternity (Fatmawati, 2013). Educated people can learn that Jesus teaches compassion and love.

\footnotetext{
Int Interview with the wife of village secretary on Friday, 3 May 2013. The village secretary (commonly known as pak carik), is the next village head that will be inaugurated at the end of May 2013

tot Interview with Ngadas village chief on Monday, May 13, 2013.
} 
Muhammad Teaches the grace and mercy of God Almighty. Buddha leads man through the middle path. Krishna teaches humans to fight the false and uphold the truth (Pendit, 2001). On this basis, people are actually invited into the understanding that all religions basically teach goodness.

However, at present, it seems cliché to say that tolerance is a matter of life and death for a very diverse society like Indonesia. Lately, with the strengthening of conservatism and the radicalization of religious views and practices, especially if competition between groups has entered the stage of religious understanding (Sutanto, 2012).

This argument does not seem to be suitable for Ngadas Village. Above the reality that the village has a diversity of religions, consciously or unconsciously, its people still apply the values of tolerance in interacting. The village is Ngadas. In the interaction of everyday life there seems to be mutual respect for each other, They believe in the law of karma. Therefore, each other always do good, not hurt and discuss any problems (Waluyo, 1997).

Religious differences in the context of Ngadas Village is not something that is considered to inhibit togetherness. For them, religion shows the same spirit, that is bringing togetherness. In fact, Hefner states, Tengger society is a society that believes all the inhabitants come from the forerunner of the village, as well as the common dependence on the spirits of the ruler of the land and water. Some confess Islam, and some are Hindu or Buddhist. But both worshiped the ancestral spirits and village protectors, emphasized the importance of communal ceremonies, and encouraged tolerance between Muslims and Hindu Buddhists (Heffner, 1999).

Tolerance, not only limited to prove with a series of words. Tolerance should also be proven by action. Establish joint villages, community service and mutual trust between citizens, proves that Ngadas practices his tolerance. In fact, this tolerance is not only aimed at the people, but also to the immigrants. The people of Ngadas do not see the background of trust as an indicator of their attitude. For them, the origin of rukun and not create chaos, openness, warmth, and hospitality will welcome the person.

The tolerant attitude shown by the Ngadas community is maintained to create harmony in this village. The lack of tolerance among religious people will threaten the harmony that has been preserved by its predecessor. In short, tolerance can be said as a concrete form of the values of harmony. Raising harmony as a foundation for the practice of tolerance values in society, the authors have finally incorporated the culture of tolerance of Tengger as the protagonist in the creation of tolerance in the village community. Tengger as a regulation of Ngadas society attitude becomes a knot that binds tolerant attitude to stay with its individuals. In other words, a society that has no religious tolerance means not identifying itself as Tengger.

For people like this, while the people are acting, but they believe that worthy rewards will be earned, this is their understanding of the concept of the Law of Karma. The law of karma, this is what the Tengger people believe (Waluyo, 1997). Its cultural identity has directed the Ngadas people to believe in this law. The law of karma, the values of harmony and tolerance have become customary for the village of Ngadas, as well as acting as the control of the behavior of people with the identity of Tengger. In accordance with the argument that says customs play a role as a social controller. Social control here serves as a deterrent to the occurrence of an act that deviates or violates the rules that apply. The cultural awakening of Tengger's culture plays an important role in the growth of this tribe, especially Ngadas Village. With these roots, the village has proven that harmony is preserved as the main value of the village community. Rooted cultural identity, grows into tolerance, with harmony as a binding knot.

Religious plurality in Ngadas Village is a portrait of life in the dressing of diversity. Tied with one identity to form a knot of tolerance, created unity. Ngadas village is still thick with its conservative culture in the middle of the modernization of Indonesia, it is more able to practice the values of unity. Religious diversity is not a barrier to society generating unity. Every individual appreciates the differences. Safe, peaceful and safe being the soul of this village. Everything is created by tolerance. With him, the people of Ngadas Village live the dynamics of life together. Mutual help and minimize conflict, all together to build togetherness for the sake of harmony.

Tolerance proved to build the foundation of this village's unity. The daily interactions and interactions of the people are always covered with warmth. Although far from civilization, the village remains confident in responding to the challenges of the country's modernity. With its unity, Desa Ngadas is able to advance to a better direction. Approximately 15 years ago, this village has not even been touched by electricity. For them, there is only one thing that limits his actions, 'Harmony'. It shows that this village prioritizes confidence. Tengger Identity invites the owner not to destroy harmony with his freedom.

Apparently not only within Ngadas Village. Other Tengger identity villages are also closely related to the value of harmony. In fact, the value of harmony is also applied between the villages of Tengger. All this is again due to tolerance $^{\S \S}$. Harmonious interaction of each village is intertwined one of them through ceremonies such as Kasada conducted every village in one region, namely Mount Bromo. Finally, this reinforces the belief of the people,

$\$ \S \S$ Interview with Ngadas village chief on Sunday, May 12, 2013. 
Tengger is the people who get along. Obviously, this states unambiguously, unity is real to the Tengger tribe. Appointing the unity of Ngadas Village should be a joint reflection for the people of Indonesia. Tolerance, Appreciation, and Recognition in the state of Bhinneka Tunggal Ika, this is what we mean by harmony (Pendit, 2001). Tolerant of tolerance, this village led to unity.

\section{Conclusion}

The most prevalent intercultural conflicts in Indonesia, pointing to the lack of a third sila actuality. Intercultural conflicts in Indonesia that arrive at the level of violence with the loss of life, has led to the impression that Indonesia is not a problem solver, but is part of the problem (Pendit, 2001). This shows the need for revitalization of the third precepts in the life of the state of Indonesia.

With the motto 'Bhinneka Tunggal Ika' (United in Diversity), the Indonesian people must understand the differences in Indonesia is not a barrier to unity. The author example through the condition of Ngadas Village, which the author considers as a miniature of Indonesia. In this village, there is also a plurality of religions. However, the condition is inversely proportional to what is in Indonesia. Conflict almost never happened in Ngadas Village. Even if there is, the community can handle it until it does not reach the quarrel and bloodshed. All problems, resolved by deliberation.

The village of Ngadas, one of Tengger's tribal villages, has a strong identity for its culture, namely Tengger. This cultural identity indirectly becomes the regulation of attitude and behavior of the people in this village. On top of the harmonious cultural values contained in this village, the identity of Tengger demands the Ngadas people to uphold these values of harmony. One support is tolerance in every society. In other words, the deepening of cultural identity has established a stem of tolerance in this village, resulting in the fruition of harmony.

In this research, the writer always associates harmony with the third principle on Pancasila, 'Persatuan Indonesia' (Indonesia Unity). Because of this harmony, the author thinks is a concrete form of unity. Harmony is proven to form harmony among religious people in the village of Ngadas. Unity in the Village Ngadas is due to the strong cultural identity of Tengger who attached to the community. From here, it proved the importance of the role of cultural identity to the unity of a group of people. Finally, learning from Ngadas Village, the author brings this concept to a wider range, namely Indonesia.

Indonesia is known for its cultural diversity. 1,128 ethnic groups in Indonesia mean that Indonesia is reasonable to have many cultures. Moving from this distinction, came the nasional motto 'bhinneka tunggal ika'. 'Bhinneka tunggal ika' and Indonesian unity can be created by what Soekarno calls "National Identity". Like the village of Ngadas, national identity will keep Indonesian unity above its cultural diversity. From the difference there is one point that binds the unity of the nation, that is identity. Thus, with unity, Indonesia is able to move forward, the differences no longer invite conflict, precisely the differences that will make Indonesia beautiful.

\section{Acknowledgements}

This work was supported by the Research Fund provided by Brawijaya University, Political Science Department, Indonesia. 


\section{References}

Chávez, S. A. R., \& Quijije, K. K. B. (2018). A Challenge for Teachers of Inclusive Higher Education. International Research Journal of Management, IT and Social Sciences (IRJMIS), 5(2), 129-135.

Faridah, I. F. (2013). Toleransi Antarumat Beragama Masyarakat Perumahan. Komunitas: International Journal of Indonesian Society and Culture, 5(1).

Haliim, W. (2014). Bangkitlah Pancasila!!: Sebuah Gagasan Kehidupan Berbangsa dan Bernegara. Universitas Brawijaya Press.

Haliim, W. Identitas Wong Tengger Masyarakat Desa Ngadas: Refleksi Kebangsaan Atas Degradasi Identitas dan Persatuan Nasional.

Hefner, R. W. (1990). The political economy of mountain Java: An interpretive history. Univ of California Press.

Hefner, R. W., Wisnuhardana, A., Ahmad, I., \& Baehaqi, I. (1999). Geger Tengger: Perubahan sosial dan perkelahian politik. Lembaga Kajian Islam dan Sosial (LKIS).

Indonesia, T. R. K. B. (2008). Kamus Bahasa Indonesia. Jakarta: Pusat Bahasa Departemen Pendidikan Nasional.

Latif, Y. (2011). Negara paripurna: historisitas, rasionalitas, dan aktualitas Pancasila. Gramedia Pustaka Utama.

Leksono, N. (2010). Sila Ketiga: Merajut Benang Rapuh Bernama Persatuan.

Mandala, H. (2018). Divergent Principles of Politeness in Verbal and Non-Verbal Directive Speech Act. International Research Journal of Engineering, IT and Scientific Research (IRJEIS), 4(2), 41-51.

Moleong, J., Lexi, M. P. K., \& Edisi Revisi, P. T. (2002). Remaja Rosdakarya.

Moleong, L. J. (2004). Metodologi Penelitian Kualitatif. Bandung: PT Remaja Rosdakarya..(2009). Metodologi penelitian kualitatif(edisi revisi).

Mulyana, D., \& Rakhmat, J. (1990). Komunikasi antarbudaya. Remaja Rosdakarya.

Pendit, N. S. (2001). Nyepi: kebangkitan, toleransi, dan kerukunan. Gramedia Pustaka Utama.

Pérez, A. V., Gámez, M. R., Briones, V. F. V., Viteri, C. G. V., \& Molina, L. A. V. (2018). Sustainable Development Seen from Environmental Training in University Linkage. International Journal of Life Sciences (IJLS), 2(1), 1220.

Purwanto, E. (2007). Representasi wong Tengger atas perubahan sosial dalam perspektif social identity theory: Studi etnografis di Desa Wonokerto dan Ngadas Probolinggo(Doctoral dissertation, Universitas Islam Negeri Maulana Malik Ibrahim).

Savitri, Alpha. (2010). Sejarah, Agama, dan Tradisi Suku Tengger Gunung Bromo. E-Book, http://wartawarga.gunadarma.ac.id/wpcontent/uploads/2010/02/sejarahAgamaTradisiTenggerBromo_AlphaSavitri_OK.pdf

Soekanto, S., \& Soemarjan, S. (1969). Sosiologi: suatu pengantar. Jajasan Penerbit Universitas Indonesia.

Suarta, I. M. (2017). Revitalization of Oral Literature Tradition of Balinese Society Based Character Values As Deradicalism Effort. International Journal of Social Sciences and Humanities (IJSSH), 1(3), 8-16.

Sudiro. (2001). Legenda dan Religi sebagai Media Integrasi Bangsa. Jurnal Humaniora, Vol. 8, No. 1, 19-30.

Sutanto, Trisno. (2012). Melampaui Toleransi: Belajar Bersama Walzer. Dalam Demi Toleransi, Demi Pluralisme. Diterbitkan dalam edisi digital di oleh Demokrasi Project.

Sutarto, A. (2006). Sekilas tentang masyarakat Tengger. Makalah disampaikan pada acara pembekalan Jelajah Budaya, 7-10.

Sutarto, A. (2006). Sekilas tentang masyarakat Tengger. Makalah disampaikan pada acara pembekalan Jelajah Budaya, 7-10.

Waluyo, H. (1997). Sistem pemerintahan tradisional di Tengger Jawa Timur. Departemen Pendidikan dan Kebudayaan, Direktorat Jenderal Kebudayaan, Direktorat Sejarah dan Nilai Tradisional, Proyek Pengkajian dan Pembinaan Nilai-Nilai Budaya.

Wirawan, I. W. A. (2018). Maintaining Social Relationship of Balinese and Sasak Ethnic Community. International Journal of Social Sciences and Humanities (IJSSH), 2(1), 92-104. 